\title{
GUW-7 AND KW-2 IGNITERS TYPES IN THE LONG-TIME STORAGE PROCESS
}

\section{ZAPLONNIKI TYPU GUW-7 I KW-2 W PROCESIE DEUGOLETNIEGO PRZECHOWYWANIA}

\author{
Dariusz Ampula \\ Wojskowy Instytut Techniczny Uzbrojenia \\ e-mail:ampulad@witu.mil.pl
}

\begin{abstract}
A statistical analysis of multiyear test results of $G U W-7$ and $K W-2$ artillery igniters type is presented in this article as representative ones to examine natural ageing process influence on indicators of quality during long-time storage. The influence of storage time on decisions connected with the quality of the lots after tests and on inconsistencies characterising the advancement level of the natural ageing process were analysed. The influence analysis of testing cycles on occurrence of inconsistences in definite classes and for the next quality decisions were carried out. The performed analysis can be essential for tests methodology of artillery igniters relevant modifications.
\end{abstract}

Keywords: storage, inconsistences, testing cycle, decision, test, properties.

Streszczenie: $W$ artykule przedstawiono analize statystyczna wieloletnich wyników badań artyleryjskich zaptonników typu $G U W-7$ i $K W-2$ jako reprezentatywnych dla badania wplywu procesu naturalnego starzenia na wskaźniki jakościowe podczas dtugoletniego sktadowania. Analizowano wplyw czasu sktadowania na decyzje dotyczace jakości partii po badaniach oraz na niezgodności charakteryzujace stopień zaawansowania procesu naturalnego starzenia. Dokonano także analizy wplywu cykli badania na wystepowanie niezgodności w ustalonych klasach oraz na kolejne decyzje jakościowe. Przeprowadzona analiza może mieć istotne znaczenie dla modyfikacji metodyki badań zapłonników artyleryjskich.

Stowa kluczowe: składowanie, niezgodności, cykl badania, decyzja, badanie, właściwości. 
GUW-7 and $K W-2$ igniters types in the long-time storage process

Zaptonniki typu GUW-7 i KW-2 w procesie dtugoletniego przechowywania

\section{Introduction}

In the set of ignition measures [ 1 ] the dominant set constitute igniters. These are multi-joint devices with initial fire and sealing up elements. They have repeatedly stronger ignition impulse in comparison with cartridge primer caps ( applied in shooting ammunition ). This is connected with their purpose to initiate the ignition pyrotechnical masses of charges in sectional cartridges and propellant charges in the solid fueled rocket missiles.

Due to way of initiating the ignition we distinguish:

- striking igniters, acting with the strike of needle, in which result follows suppression and ignition of primer cap,

- electric igniters, acting with electrical impulse, the ignition of primer causes electrical spark passage or warmed with electric current glowing element,

- electrically - striking igniters, called also double action igniters, having elements of electric and striking igniter.

Striking igniters generally apply in the most of sectional ammunition. Electrical and electrically - striking igniters are applied in rapid - fire guns and to shooting guns on the run to mobile targets cartridges ( sea and tank guns ), as the way of remote and accelerated ignition.

Due to way of connection of the igniter with cartridge we distinguish:

- igniters screwed in bottom case of cartridge,

- igniters pressed in hole bottom of case,

- igniters put into the lock applied in caseless cartridges.

Screwed and pressed igniters are permanently connected to cartridge by thread or press, however put igniters are treaded as the separate element of the cartridge till the moment of loading of the cannon.

Regardless of construction solutions all kind and types of igniters consist of: body, primer cap and incendiary charge. The body joins all parts and groups of igniter into one piece and protects it from damages and atmospheric factors, particularly moistures. The puncture primer cap in striking igniter or electrical in electric igniter or both in electrically - striking igniter initiate fire chain which follows the ignition of remaining parts of incendiary charge. Powder incendiary charge occurs in the pressed detonator form and loosely strewn black powder or one of these elements. They are used in producing the suitable temperature of fire stream guaranteeing reliable inflammation of the charge.

The quality of igniters are determined by the reliable working igniters the safety during exploitation and the durability and the resistance on conditions prevailing during long-time storage in the armies.

The most important properties of igniters are these which characterise the safety in the process exploitation, reliability working and resistance on prevailing conditions during long-time storage. These are so-called exploitive properties. The most desirable are properties suitable for empirical tests and simultaneously characterising the qualitative state of igniters. 
To them belong: the bodies endurance, the correctness of assembly, the content of moisture in incendiary charges, the corrosion resistance, the physical condition of cubes (pressed incendiary charges), the sensibility and ignition incendiary changes abilities, the initiating working of incendiary changes, the reliability working of fire chain and sealing up mechanism, uncontrolled work of igniter during loading to the cartridge chamber.

In case of electric and electrically - striking igniters tests are performed: the resistance of igniter isolation, the resistance of bridge on the safety with the electric current, the working reliability from the current impulse with the time measurement of getting down to work.

The appearance in the sample of igniters given lot, an inconsistencies with established requirements for every subject feature in the classification according to importance (weights) for the safety, the reliability working and the resistance on conditions of long-time storage.

Properties (features) are divided on four importance classes: A, B, C and D. Classes $\mathrm{C}$ and $\mathrm{D}$ characterise safety and working reliability in the exploitation process, classes $\mathrm{A}$ and $\mathrm{B}$ - the degree of advancing process of natural aging.

\section{The quality analysis of igniters}

The GUW-7 electrically - striking and KW-2 striking igniters types which have not been analysed yet, were subject of statistical analysis. The author of this article undertook an attempt to conduct analysis of this type igniters. GUW-7 igniters have two primer caps and are applied in $125 \mathrm{~mm}$ D-81 cartridges with homogenous high velocity projectile, with core high velocity projectile, with anti-tank projectile and with high explosive projectile. However, KW-2 type igniters are applied in 37 mm A-39 cartridges with fragmentation - tracer projectile armed in fuse and unarmed and with armour - piercing - tracer projectile. The readers interested in the construction and working this type of igniters should look at [1].

The executed analysis of igniters includes all previous laboratory test results which were performed in Military Institute of Armament Technology to the end of 2010. The next test results were not considered due to new methodology introduction.

Diagnostic tests of igniters carried out according to binding to the end of 2010 methodology of diagnostic tests of ammunition Index N-5001b. The aim of this analysis is to recognize the natural aging process of igniters and influence of these processes on their qualitative coefficients.

In practice the statistical test of influence that one factor has no another one is a study of mutual dependence between these factors. The most essential dependences which show mutual relations of analysed values are presented in the article. The methods of regression analysis and correlation allow to evaluate and definite tendency of dependence applied to the statistical analysis. The Statsoft Poland company software [ 3 ] was used. In the article there are not presented all of elaborated graphs. Only the most essential graphs which can indicate on existence dependence between considered measures were analysed. 
GUW-7 and $K W-2$ igniters types in the long-time storage process

Zaptonniki typu GUW-7 i KW-2 w procesie dlugoletniego przechowywania

\section{Storing time and diagnostic decisions}

The most general indicator of quality for stored lots of igniters is a decision referring to this lot, that is taken after testing the samples from the lot. The set of all decisions is divided into two subsets for the aims of presented analysis: the subset of positive decisions and subset of negative decisions. The subset of positive decisions includes decisions B5 and B3, these are decisions about lot compatibility with requirements and its suitability for using and storing in the next 3 or 5 years. All remaining diagnostic decisions belong to subset of negative decisions.

An influence effect of the lots storage time is the occurrence during this storage the senescence changes of igniters, able to cause inconsistencies due to individual properties. The quality of entire lot sets of given kind of igniters in the moment of test could depends on decision about quality of undertaken lots as result of their previous diagnostic tests.

During testing the tendency of this dependence accepted, that dependent variable is the fraction (the percentage) of undertaken positive decisions. As independent variable was accepted with storage time to the moment of test. This time is counted in years as difference between the year of test and year of the production tested lot. The fraction is a relation between the number of undertaken positive decisions and the general number undertaken decisions in given storage year.

On the figures 1 and 2 fraction (percentage) of positive decisions depending on storage time for igniters type GUW-7 is presented. The second graph shows the dispersion received from test results. The longer storage time, the more increased the percentage (fraction) positive decisions what testifies the positive linear coefficient of correlation carrying out $r=0,10163$.

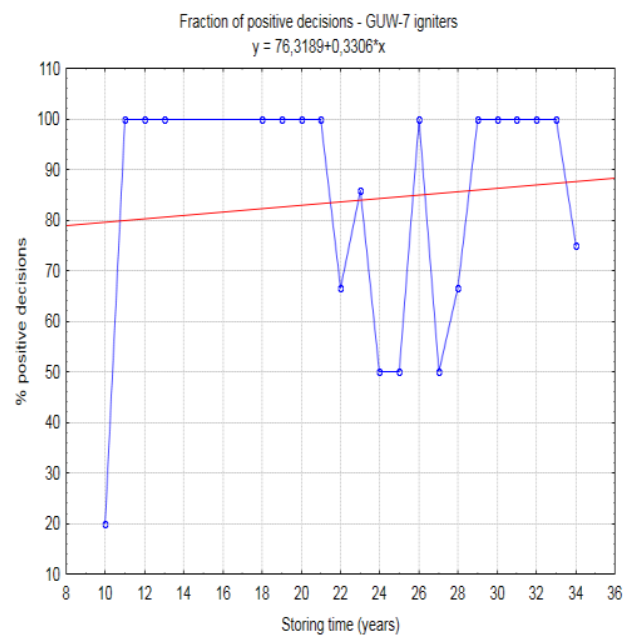

Fig.1 Graph of dependence between time of storing until the moment of test and fraction of positive decision for GUW-7 igniters.

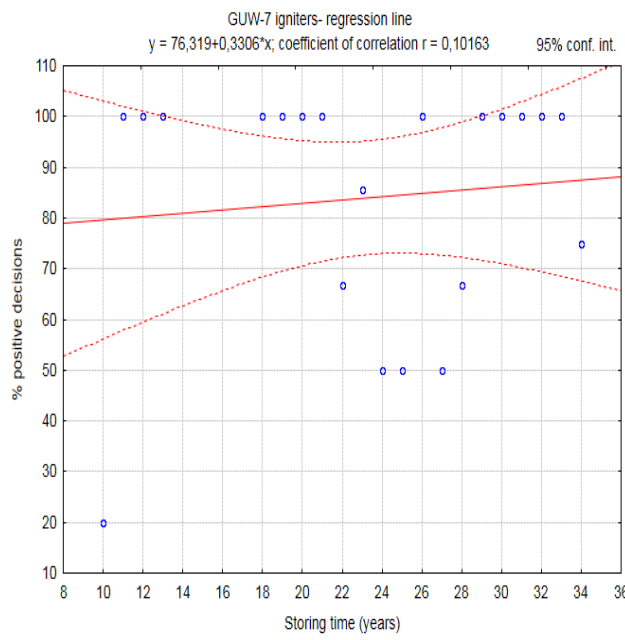

Fig.2 Graph of data dispersion and regression line describing these data together with determining confidence interval for GUW-7 igniters. 
The figures 3 and 4 introduce the fraction of positive decisions depending on storage time for $\mathrm{KW}-2$ igniters. The negative linear coefficient of correlation carrying out $r=-0,5613$ informs us about the large decrease of this fraction in proportion of the storage time growth.

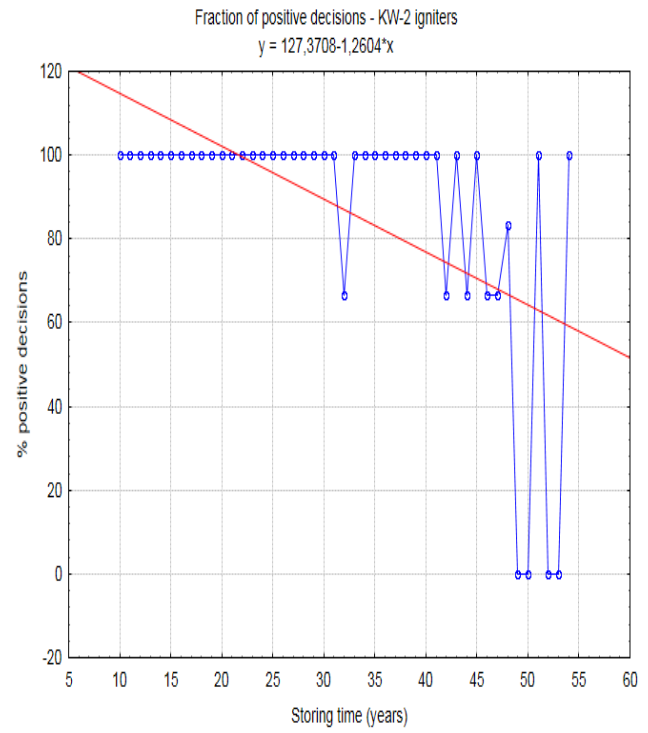

Fig.3 Graph of dependence between time of storing until the moment of test and fraction of positive decision for $K W$-2 igniters

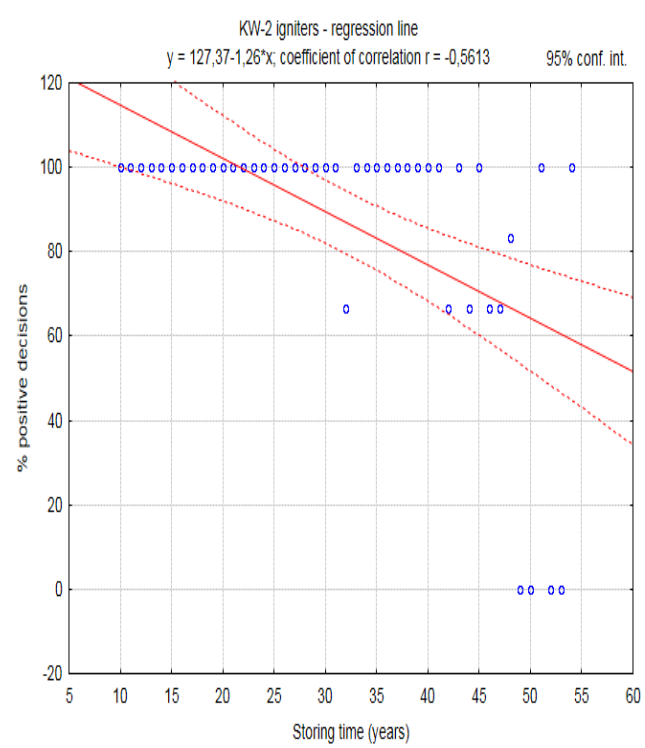

Fig.4 Graph of data dispersion and regression line describing these data together with determining confidence interval for $K W$-2 igniters

Curve courses on figures $1 \div 4$ indicate an existence of small growing tendency for GUW-7 igniters and about considerable decreasing fraction tendency of positive decisions for KW-2 igniters. Time running has a negative influence on KW-2 type igniters because of decline of quality of these lot sets of igniters of long standing stored.

\section{Testing cycle and diagnostic decisions}

Conducted diagnostic tests of igniters lot sets are a factor which can have an influence on the quality of long standing sets of igniters. As a result of these systematic tests lots unfitting the discordant with requirements are removed. Consequently in the next test cycles, the quality set of igniters lots should rally. For the purpose of fuller test this phenomenon carried out analysis of dependence fraction (percentage) of positive decisions from storage time in the next testing cycle. As an independent variable the storage time was accepted and as dependent variable percentage of positive decisions. 
GUW-7 and $K W-2$ igniters types in the long-time storage process Zaptonniki typu GUW-7 i KW-2 w procesie dtugoletniego przechowywania

Figures $5 \div 11$ crossed received percentages of positive decisions for next test cycle of storage time suitably for GUW-7 and KW-2 igniters depending considered in this analysis.

GUW-7 igniters were tested only in two test cycles, however KW-2 igniters reached five test cycles. The figure 5 shows us fraction of positive decisions undertaken in the first test cycle depending on storage time for GUW-7 igniters. This graph shows, that this dependence has downward tendency whereabout testifies the negative coefficient of correlation $r=-0,3776$, that is in proportion passage store time are followed deterioration quality level of analysed igniters. Figure 6 shows fraction of positive decisions undertaken in the second test cycle it is visible, that this fraction has growing tendency. The linear coefficient of correlation carries out $r=0,57627$, that is follows considerable quality improvement of GUW-7 igniters stored lots set in this test cycle.

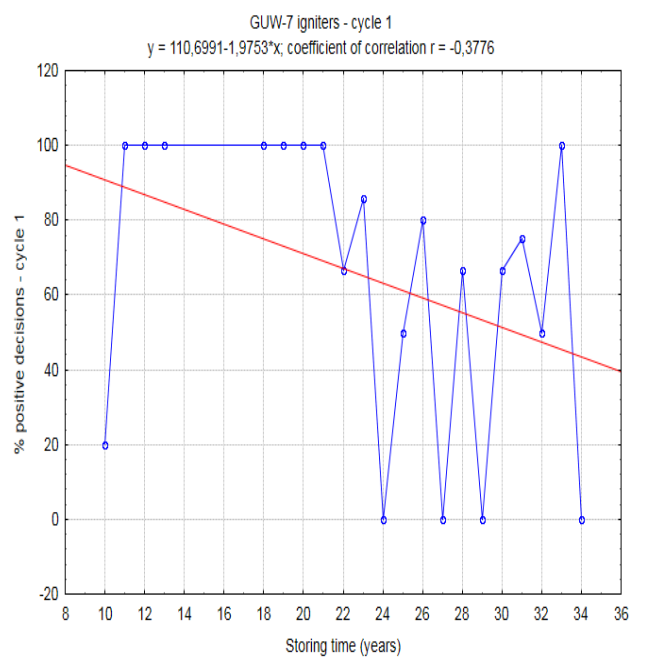

Fig.5 Fraction positive decisions in the first test of cycle depending on storing time for $G U W-7$ igniters

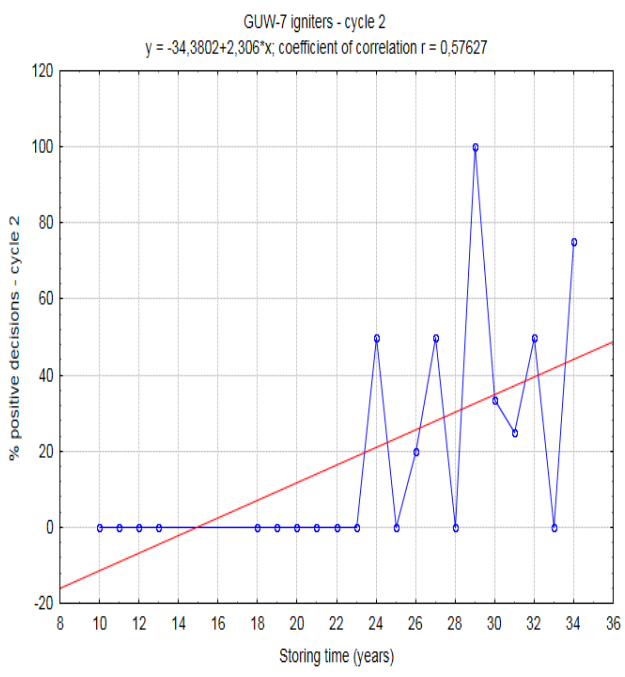

Fig.6 Fraction positive decisions in the second test of cycle depending on store time for GUW-7 igniters

The graphs presented on figures $7 \div 11$ concern KW-2 igniters. The figure 7 shows fraction of positive decisions undertaken in the first test cycle depending on storage time. A large coefficient of correlation value carrying out $r=-0,8432$, tells us about violent decrease of quality level sets of these igniters. In the second test cycle (Fig. 8) we see practically the constant quality level because the regression curve is almost horizontal $(r=-0,0355)$. The figures $9 \div 11$ show fraction of positive decisions in the next test cycles that is from 3 to 5 . In all these cycles it is visible, that regression curve has increasing tendency. Linear coefficients of correlation carry out $0,23695 \div 0,34449$. 


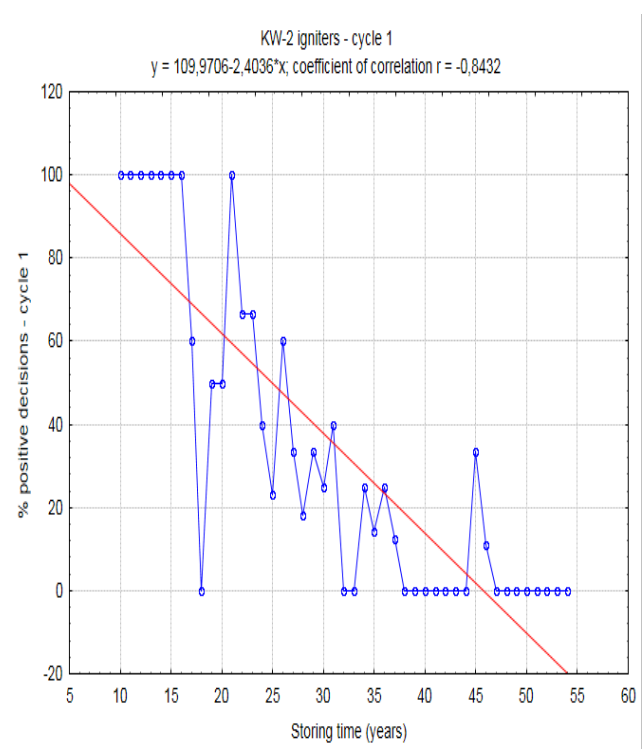

Fig.7 Fraction positive decisions in the first test of cycle depending on storing time for $K W-2$ igniters

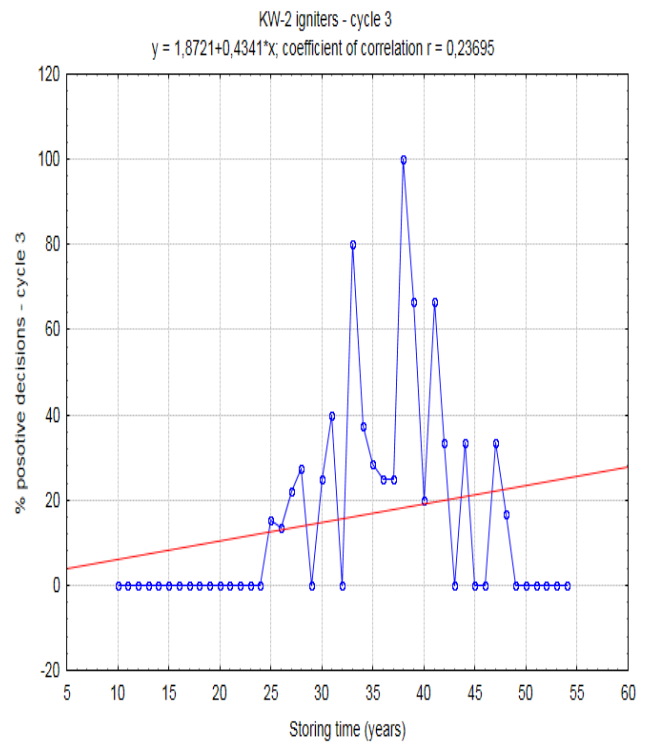

Fig.9 Fraction positive decisions in the third test of cycle depending on storing time for $K W$-2 igniters

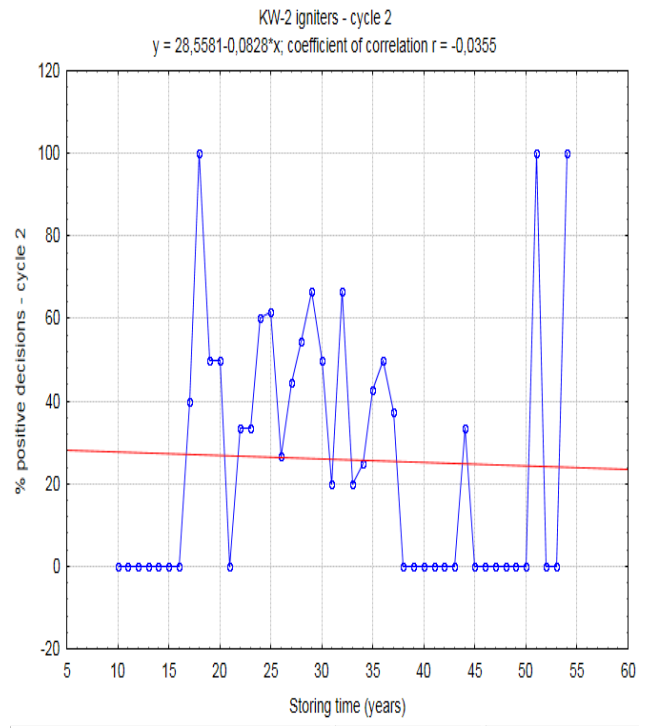

Fig.8 Fraction positive decisions in the second test of cycle depending on storing time for $K W$-2 igniters

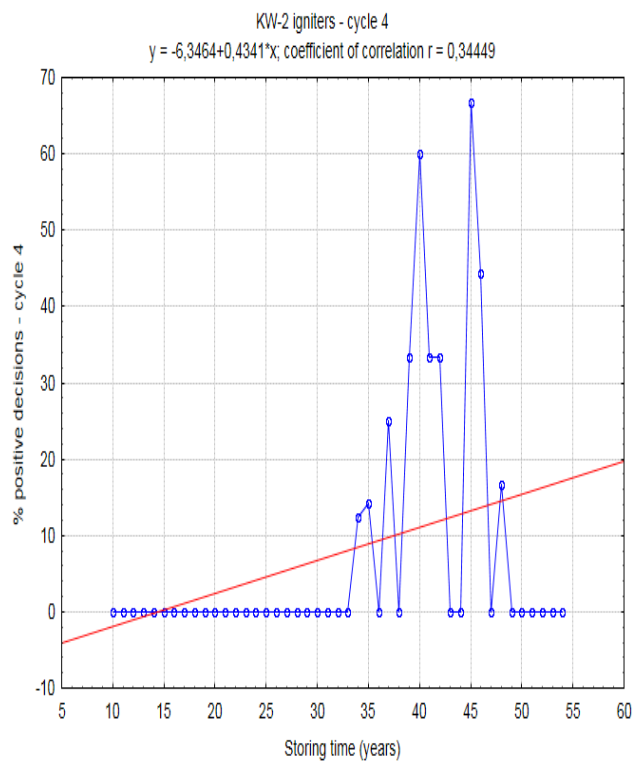

Fig.10 Fraction positive decisions in the fourth test of cycle depending on storing time for $K W$-2 igniters 
GUW-7 and $K W-2$ igniters types in the long-time storage process Zaptonniki typu GUW-7 i KW-2 w procesie dtugoletniego przechowywania

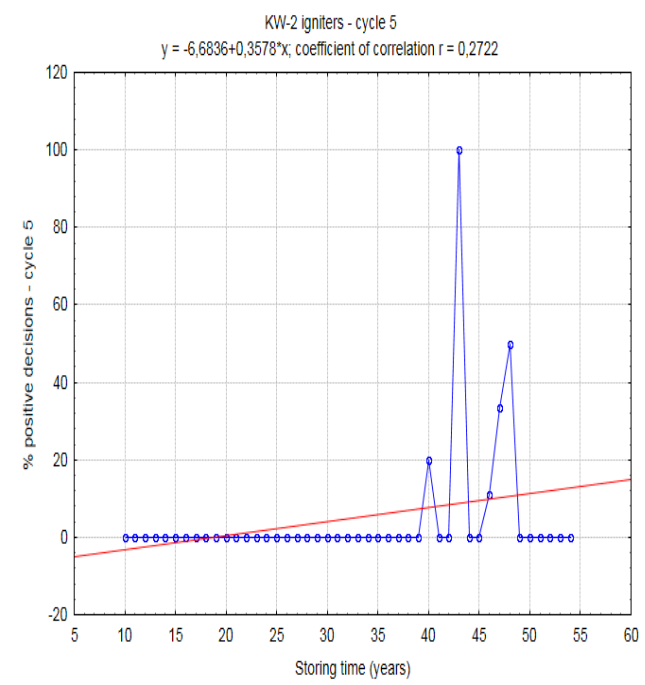

Fig.11. Fraction positive decisions in the fifth test of cycle depending lon storing time for $K W$-2 igniters.

\section{The influence of testing cycle on inconsistencies}

During conducting diagnostic tests, a lot of igniters tested in the first testing cycle after 10 years of storage are not always tested in the second cycle in 16 years of storage. Also the first testing cycle often is begun in different years of storage. Mainly this was the reason of allocating annually more and more smaller financial means on the test elements of ammunition. In this analysis undertaken an attempt to define occurrences inconsistencies of individual classes depending on the next testing cycle was undertaken.

In the case of igniters KW-2 type, crossed of such curves was possible in consideration to the fact, that these igniters were tested in five testing cycles. However, in the case of GUW-7 igniters, we can cross such curves, although it will be only straight lines about very small tendency of changes in consideration of the fact, that they were tested only in the two testing cycles. At so small quantity of data (only two points) it is not possible is define for example, linear coefficient of correlation. The minimal amount of observation necessary to make definition is at least three points.

From the data results elaborated for igniters GUW-7 type results, that fraction of inconsistencies of given class depending on testing cycle is whether growing as in case of inconsistencies class A and C, or decreasing as in case of inconsistencies class B and D. However, the presentation of these data in the graphs form, do not bring reliable information which should be infer after crossed of such curves. Few quantity of testing cycles in case of this type igniters type caused few quantity of carried out tests.

In the case KW-2 igniters, fractions of inconsistencies definite classes depending on testing cycle present figures $12 \div 15$. In case of inconsistencies class $\mathrm{A}$ and $\mathrm{B}$ we have very large decreasing fraction of inconsistencies of these classes. Coefficients of correlation carry out for inconsistencies class A $r=-0,8908$ (Fig. 12), and in case of inconsistencies class B this coefficient carry out $r=-0,929$ (Fig. 13). 


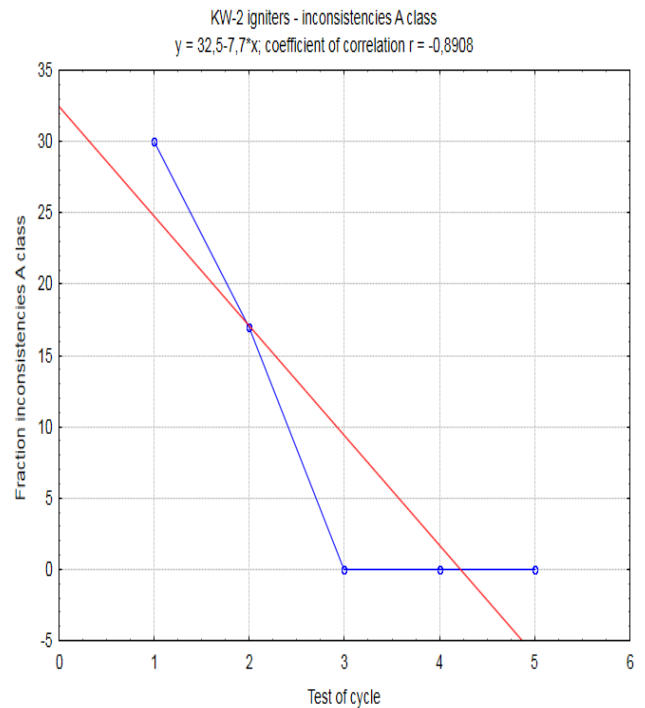

Fig.12 Fraction inconsistencies A class in the dependence from test of cycle for $K W-2$ igniters

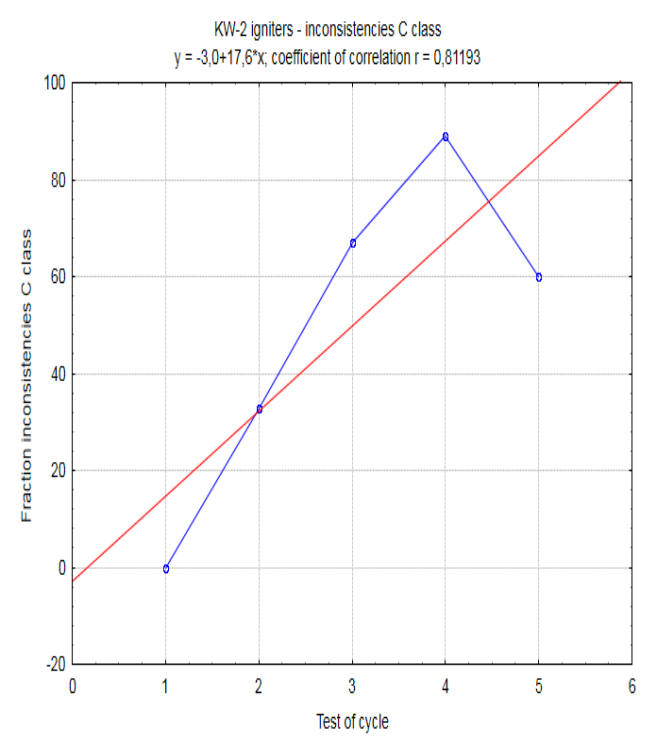

Fig.14. Fraction inconsistencies $C$ class in the dependence from test of cycle for $K W$-2 igniters

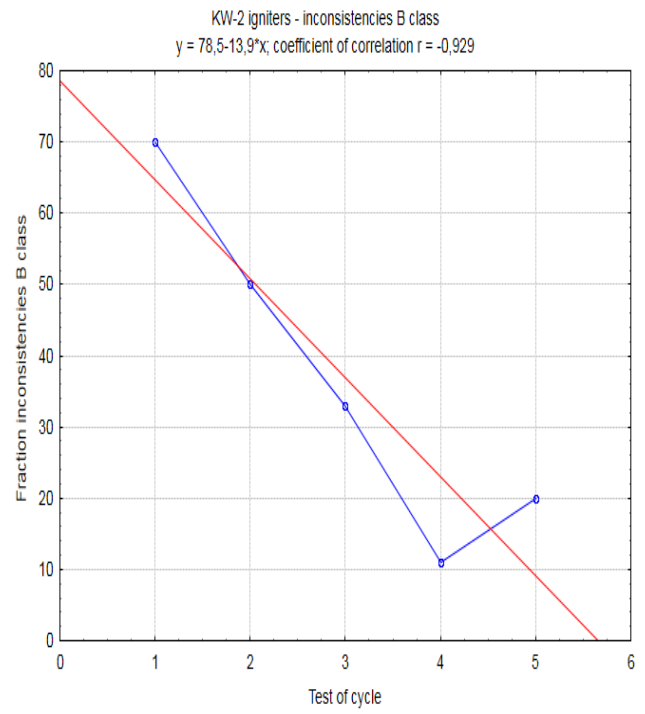

Fig.13 Fraction inconsistencies B class in the dependence from test of cycle for $K W$-2 igniters

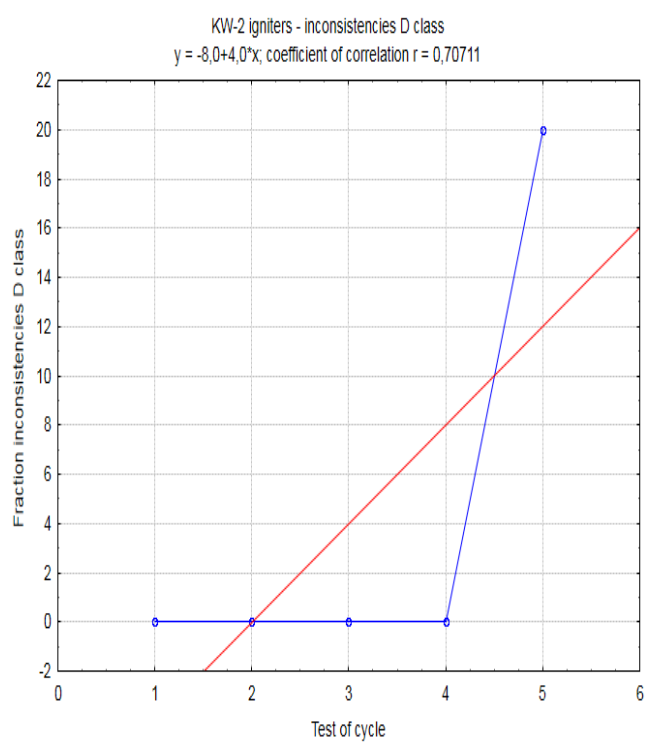

Fig.15. Fraction inconsistencies $D$ class in the dependence from test of cycle for $\mathrm{KW}-2$ igniters 
GUW-7 and $K W-2$ igniters types in the long-time storage process Zaptonniki typu GUW-7 i KW-2 w procesie dtugoletniego przechowywania

However, for inconsistencies classes $\mathrm{C}$ and $\mathrm{D}$ there are growing fractions of inconsistencies of these classes. Coefficients of correlation carry out for inconsistencies class C $r=0,81193$ (Fig. 14), and for inconsistencies class D $r=0,70711$ (Fig. 15). As it is visible from presented graphs, the tendency of curves changes is different depending on considered class of inconsistencies. The definition uniform conclusions concerning of the influence determined classes of inconsistencies on the quality level of considered lot sets of KW-2 igniters type is very difficult. On these figures, for the purpose of more accurate image tendency of changes, crossed also regression line for these analysed igniters.

\section{The influence of storing time on inconsistencies}

Discussed in the point 5 the dependence of occurrence inconsistencies determined class from testing cycle is connected with storage time. Consecutive testing cycles of given lot happen in later periods of storing time. This dependence is not functional, because the start of the first testing cycle happens in various moments of lot storing time and moreover the time expiring between consecutive testing cycles is different for various stored lots set.

The dependence between fractions of samples with inconsistencies belonging to individual classes of inconsistencies and storing time of igniters lots is a next subject of the analysis. As an independent variable the storing time till the moment of testing is taken. The fractions of samples with inconsistencies for particular classes for igniters analysed in this article were shown on the figures $16 \div 18$.

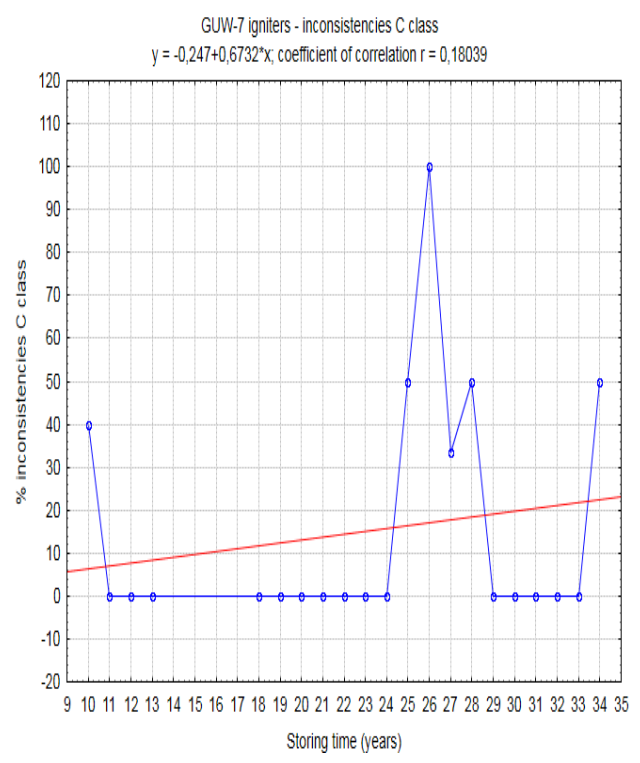

Fig.16. Fraction inconsistencies $C$ class in the dependence from storing time for GUW-7 igniters

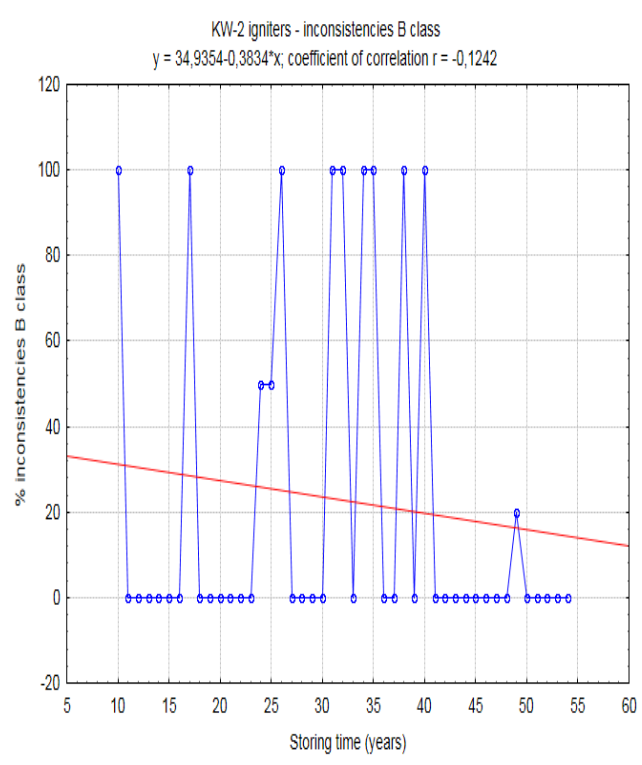

Fig.17. Fraction inconsistencies $B$ class in the dependence from storing time for $K W$-2 igniters 


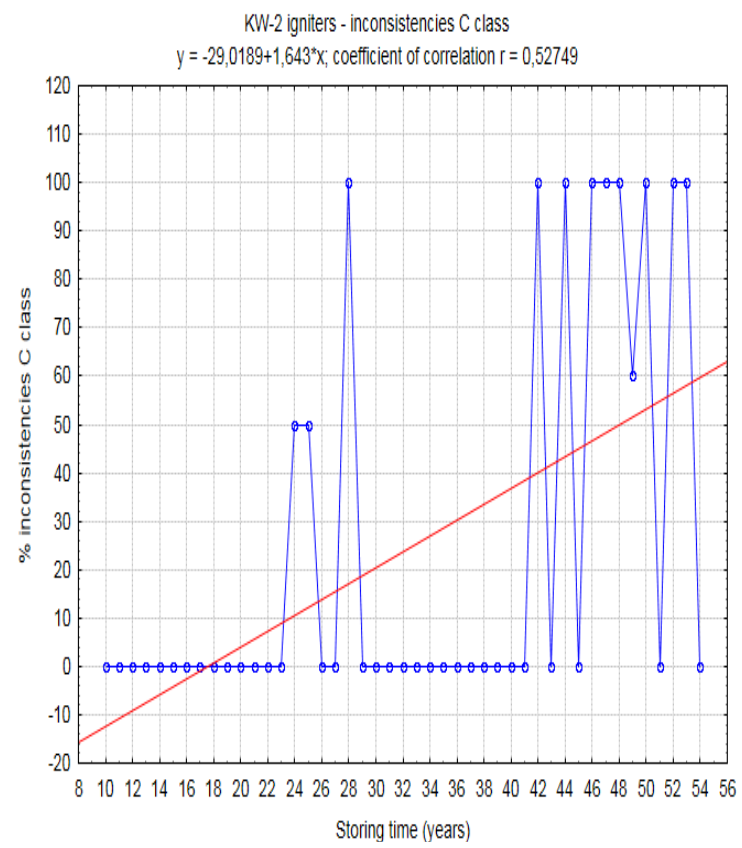

Fig.18. Fraction inconsistencies $C$ class in the dependence from storing time for $\mathrm{KW}$-2 igniters.

The graph of dependence between fractions of inconsistencies class $\mathrm{C}$ and the storing time for igniters GUW-7 type are shown on the figure 16. In this case class of inconsistencies there are visible growing tendency what evidently underlines fact that the quality of long stored type of igniters decreases. Coefficient of correlation carry out for this class of inconsistencies $r=0,23715$. However, in the case of inconsistencies of class A, B and D was not analysed obtained results due to the too few quantity received inconsistencies of these classes during tests carried out. In the case of KW-2 igniters, fractions of inconsistencies of individual classes depending on storage time were presented on figures 17 and 18 .

In case fractions of inconsistencies class B (Fig. 17) we have to deal with decreasing fraction of inconsistencies this class. The linear coefficient of correlation carries out $r=-0,1242$. However, for fraction of inconsistencies class $\mathrm{C}$ we see growing fraction of inconsistencies this class. The coefficient of correlation carried out $r=0,52749$ (Fig. 18).

Fractions of inconsistencies classes $\mathrm{A}$ and $\mathrm{D}$ were not considered due to the too few quantity test results of inconsistencies of these classes. 
GUW-7 and $K W-2$ igniters types in the long-time storage process

Zaptonniki typu GUW-7 i KW-2 w procesie dtugoletniego przechowywania

\section{References}

In the case of analysed igniters the dependence between fraction of positive decisions and storage time has a slightly growing tendency and is a positive dependence for GUW-7 igniters type, however for $\mathrm{KW}-2$ igniters type this dependence has a tendency decreasing strongly.

The course of regression line clearly indicates fact of the worsening quality state of lot sets igniters of this type in proportion passage of storage time.

The analysis dependence fraction of positive decision in the individual testing cycles depending on storage time showed, that this fraction has different tendency depending on considered testing cycle. It has a decreasing tendency in case of the first cycle for both types of analysed igniters and increasing tendency for KW-2 igniters in testing cycle from 3 to 5 and for GUW-7 igniters in the second testing cycle. In case of analysis the dependence fraction of inconsistencies individual classes in relation to the testing cycle we see, that these fraction have also a different tendency of changes depending on considered type of igniter. It is visible different tendencies changes of inconsistencies different classes for analysed igniters. In case of KW-2 igniters, inconsistencies classes A and B have decreasing tendency, that is the quality level of these igniters improves due to these classes of inconsistencies, however inconsistencies classes $\mathrm{C}$ and D show increasing tendency, what can testify about worsening quality state of stored igniters due to inconsistencies of these classes.

GUW-7 igniters type show also alternately tendency of changes depending on kind of inconsistencies. However, too few quantity of testing cycle for these igniters are effective the lack of possibility elaboration of reliable graphs to carried out analysis.

The analysis fraction of inconsistencies individual classes depending on storage time showed, that this fraction has also different tendency depending on considered class of inconsistencies and from type of the igniter. In case of GUW-7 igniters type, we could have analysed only inconsistencies class $\mathrm{C}$, which have increasing tendency in proportion passage storing time. Remaining inconsistencies were not analysed in consideration of too few quantity test results in these classes of inconsistencies. In KW-2 igniters inconsistencies classes B and C were analysed. Inconsistencies class B showed decreasing tendency, however inconsistencies class $\mathrm{C}$ increasing tendency.

As result of conducting diagnostic tests, from stored lot sets of igniters are removed lots discordant with requirement, thanks to this the level of their quality should improve or maintain on the constant good qualitative level enabling normal their exploitation. Unfortunately, analysis carried out of GUW-7 and KW-2 igniters types does not confirm this. Despite the wide range of this analysis, taking into account many possible analysed measures, it is difficult to draw uniform conclusions. Depending on the kind of analysed measures, tendencies of changes for considered types of igniters are different. 


\section{Literature}

[1] Handbook - Ammunition of Land Forces - Ministry of National Defence, Warsaw 1985;

[2] The group work - Methodology of diagnostic test of ammunition - Index N5001b - 1985, Archive of Military Institute of Armament Technology (MIAT);

[3] The statistics 9 - Statsoft Poland 2009 - the computer software;

[4] M. Rabiej - The statistics with the program Statistica - The publishing house Helion, Gliwice 2012;

[5] S. Kot, J. Jakubowski, A. Sokołowski - The statistics - The publishing house Difin, Warsaw 2011.

[6] Cards of tests of igniters - the archive of MIAT.

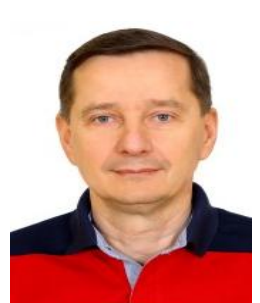

Dariusz Ampula DSc. Eng., graduated Military Technical Academy in the area of the Ground Armament Systems. He became the scientifically - test worker at Military Institute of Armament Technology in Zielonka after holding of one year professional practice. The degree scientific of doctor he obtained in 2006 in Air Force Institute of Technology. The author and co-author of works from the area technical diagnostics and reliability of working land ammunition. In his analytical analysis he focuses on the problems of prediction process tested elements of land ammunition. 
GUW-7 and $K W-2$ igniters types in the long-time storage process

Zaptonniki typu GUW-7 i KW-2 w procesie dtugoletniego przechowywania

\section{ZAPLONNIKI TYPU GUW-7 I KW-2 W PROCESIE DLUGOLETNIEGO PRZECHOWYWANIA}

\section{Wstęp}

W zbiorze środków zapłonowych [ 1 ] dominujący zbiór stanowią zapłonniki. Są to urządzenia wielozespołowe $\mathrm{z}$ elementami inicjującymi ogniowymi i uszczelniającymi. W porównaniu $\mathrm{z}$ nabojowymi spłonkami zapalającymi (stosowanymi $\mathrm{w}$ amunicji strzeleckiej) mają wielokrotnie silniejszy impuls zapłonowy. Jest to związane z przeznaczeniem ich do inicjowania zapłonu mas pirotechnicznych ładunków miotających $w$ nabojach działowych i ładunków napędowych w pociskach rakietowych na paliwo stałe.

Ze względu na sposób inicjowania zapłonu rozróżnia się:

- zapłonniki uderzeniowe, działające od uderzenia iglicy, w wyniku którego następuje zgniot i zapłon spłonki zapalającej,

- zapłonniki elektryczne, działające od impulsu elektrycznego, zapłon spłonki powoduje przeskok iskry elektrycznej lub rozgrzany prądem elektrycznym element żarzący,

- zapłonniki elektryczno - uderzeniowe, zwane również zapłonnikami podwójnego działania, mające elementy zapłonnika elektrycznego i uderzeniowego.

Zapłonniki uderzeniowe stosuje się powszechnie w większości amunicji działowej. Zapłonniki elektryczne i elektryczno - uderzeniowe stosuje się w nabojach do dział szybkostrzelnych oraz do dział strzelających w ruchu do celów ruchomych (działa morskie i czołgowe), jako sposób zdalnego i przyspieszonego odpalania.

Ze względu na sposób połączenia zapłonnika z nabojem rozróżnia się:

- zapłonniki wkręcane w dno łuski naboju,

- zapłonniki wprasowywane w otwór dna łuski,

- zapłonniki wkładane w zamek, stosowane w nabojach bezłuskowych.

Zapłonniki wkręcane i wprasowywane są trwale połączone z nabojem za pomocą gwintu lub wcisku, natomiast zapłonniki wkładane stanowią do chwili załadowania działa - oddzielny element naboju.

Bez względu na rozwiązania konstrukcyjne wszystkie rodzaje i typy zapłonników składają się z kadłuba, spłonki zapalającej i ładunku zapalającego. Kadłub łączy wszystkie części i zespoły zapłonnika $\mathrm{w}$ jedną całość i zabezpiecza je przed uszkodzeniami oraz działaniem czynników atmosferycznych, szczególnie wilgoci. Spłonka zapalająca nakłuciowa $\mathrm{w}$ zapłonniku uderzeniowym lub elektryczna w zapłonniku elektrycznym, bądź obydwie w zapłonniku elektryczno uderzeniowym stanowią pierwszy inicjujący element w łańcuchu ogniowym, od którego następuje zapłon pozostałych części ładunku zapalającego. Prochowy ładunek zapalający występuje w postaci sprasowanej petardy i luźno nasypanego prochu czarnego lub jednego $\mathrm{z}$ tych elementów. 
Służą one do wytworzenia odpowiedniej temperatury strumienia ognia gwarantującego niezawodne zapalenie ładunku miotającego.

O jakości zapłonników decyduje ich niezawodne działanie, bezpieczeństwo podczas eksploatacji oraz trwałość i odporność na warunki panujące w czasie długoletniego składowania w wojskach.

Do najważniejszych właściwości zapłonników należą te, które charakteryzują bezpieczeństwo $\mathrm{w}$ procesie eksploatacji, niezawodność działania i odporność na warunki panujące podczas długoletniego składowania. Są to tzw. właściwości eksploatacyjne. Najbardziej pożądane są właściwości poddające się empirycznym badaniom i jednocześnie charakteryzujące stan jakościowy zapłonników. Do nich należą: wytrzymałość korpusów, prawidłowość montażu, zawartość wilgoci w ładunkach zapalających, odporność na korozję, stan fizyczny kostek (wyprasek ładunków zapalających), wrażliwość i zdolności zapłonowe spłonek zapalających, działanie inicjujące ładunków zapalających, niezawodność działania łańcucha ogniowego i mechanizmu uszczelniającego, zadziałanie niekontrolowane zapłonnika podczas ładowania do komory nabojowej.

W przypadku zapłonników elektrycznych i elektryczno - uderzeniowych wykonywane są także badania: oporności izolacji zapłonnika, oporności mostka na bezpieczeństwo prądem, niezawodności działania od impulsu prądowego z pomiarem czasu zadziałania.

Wystąpienie $\mathrm{w}$ próbce zapłonników danej partii, niezgodności z wymaganiami ustalonymi dla każdej cechy, poddaje się klasyfikacji według ważności (wagi) dla bezpieczeństwa, niezawodności działania i odporności na warunki długoletniego składowania.

Właściwości (cechy) podzielone są na cztery klasy ważności: A, B, C i D. Klasy $\mathrm{C}$ i D charakteryzują bezpieczeństwo i niezawodność działania w procesie eksploatacji, klasy A i B - stopień zaawansowania procesu naturalnego starzenia.

\section{Analiza jakości zapłonników}

Analizie statystycznej poddano zapłonniki elektryczno-uderzeniowe typu GUW-7 oraz zapłonniki uderzeniowe typu KW-2, które nie były do tej pory analizowane. Autor artykułu podjął więc próbę przeprowadzenia analizy tego typu zapłonników. Zapłonniki GUW-7 posiadają dwie spłonki zapalające i są stosowane w $125 \mathrm{~mm}$ nabojach D-81 $\mathrm{z}$ pociskiem podkalibrowym jednolitym, $\mathrm{z}$ pociskiem podkalibrowym $\mathrm{z}$ rdzeniem, $\mathrm{z}$ pociskiem kumulacyjnym oraz $\mathrm{z}$ pociskiem odłamkowo-burzącym. Natomiast zapłonniki typu KW-2 są stosowane w $37 \mathrm{~mm}$ nabojach A-39 z pociskiem odłamkowo - smugowym uzbrojonym w zapalnik i nieuzbrojonym oraz z pociskiem przeciwpancerno - smugowym. Czytelników zainteresowanych budową i działaniem tego typu zapłonników odsyłam do [1].

Wykonana analiza obejmuje wszystkie dotychczasowe wyniki badań laboratoryjnych zapłonników jakie zostały wykonane w WITU do końca 2010 roku. Późniejsze wyniki badań nie były rozpatrywane ze względu na wprowadzenie nowej metodyki badawczej. 
GUW-7 and $K W-2$ igniters types in the long-time storage process

Zaptonniki typu GUW-7 i KW-2 w procesie dtugoletniego przechowywania

Badania diagnostyczne zapłonników przeprowadzono zgodnie z obowiązującą do końca 2010 roku metodyką badań diagnostycznych amunicji Indeks N-5001b. Celem tej analizy jest poznanie procesów naturalnego starzenia zapłonników oraz wpływu tych procesów na ich wskaźniki jakościowe.

W praktyce statystyczne badanie zależności jednego czynnika na inny sprowadza się do badania zależności między tymi czynnikami. W artykule przedstawiono jedynie najistotniejsze zależności, które pokazują istniejącą wzajemną relację analizowanych wielkości.

Do analizy statystycznej zastosowano zatem metody analizy regresji i korelacji pozwalające na ocenę i określenie charakteru zależności. Wykorzystano oprogramowanie [3] firmy Statsoft Polska. Nie przedstawiono w artykule wszystkich opracowanych wykresów. Przeanalizowano jedynie te najistotniejsze wykresy, które mogą wskazywać na istnienie zależności pomiędzy rozpatrywanymi wielkościami.

\section{Wpływ czasu składowania na decyzje diagnostyczne}

Najbardziej ogólnym wskaźnikiem jakości składowanych partii zapłonników jest decyzja dotycząca tej partii, podjęta po zbadaniu pochodzącej z niej próbki. Dla celów niniejszej analizy zbiór wszystkich decyzji podzielono na dwa podzbiory: podzbiór decyzji dodatnich i podzbiór decyzji ujemnych. Do podzbioru decyzji dodatnich zaliczono decyzje B5 i B3, a więc decyzje o zgodności partii z wymaganiami oraz jej zdatności do użytku i składowania przez kolejnych 3 lub 5 lat. Do podzbioru decyzji ujemnych ( negatywnych ) zaliczono wszystkie pozostałe decyzje diagnostyczne.

Efektem wpływu czasu składowania partii jest występowanie w czasie tego składowania zmian starzeniowych zapłonników, mogących powodować niezgodności ze względu na poszczególne właściwości. Przyjęto, że jakość całego zbioru partii danego rodzaju zapłonników w danej chwili badania może zależeć od decyzji o jakości tych partii podjętych w wyniku ich uprzednich badan diagnostycznych.

Przy badaniu charakteru tej zależności przyjęto, że zmienną zależną jest frakcja (procent) podjętych decyzji dodatnich. Jako zmienną niezależną przyjęto czas składowania partii do chwili danego badania. Czas ten jest liczony w latach jako różnica między rokiem danego badania i rokiem produkcji badanej partii. Frakcja jest zatem stosunkiem liczby podjętych decyzji dodatnich do ogólnej liczby decyzji podjętych w danym roku składowania.

Na rysunkach 1 i 2 przedstawiono frakcję (procent) decyzji dodatnich w zależności od czasu składowania dla zapłonników typu GUW-7 z tym, że wykres drugi pokazuje nam wykres rozrzutu otrzymanych wyników badań. $Z$ wykresów tych wynika, że w miarę upływu czasu składowania, wzrasta procent (frakcja) decyzji dodatnich o czym świadczy dodatni współczynnik korelacji liniowej wynoszący $r=0,10163$. Natomiast na rysunkach 3 i 4 przedstawiono frakcję decyzji dodatnich w zależności od czasu składowania dla zapłonników KW-2. 
Dariusz Amputa

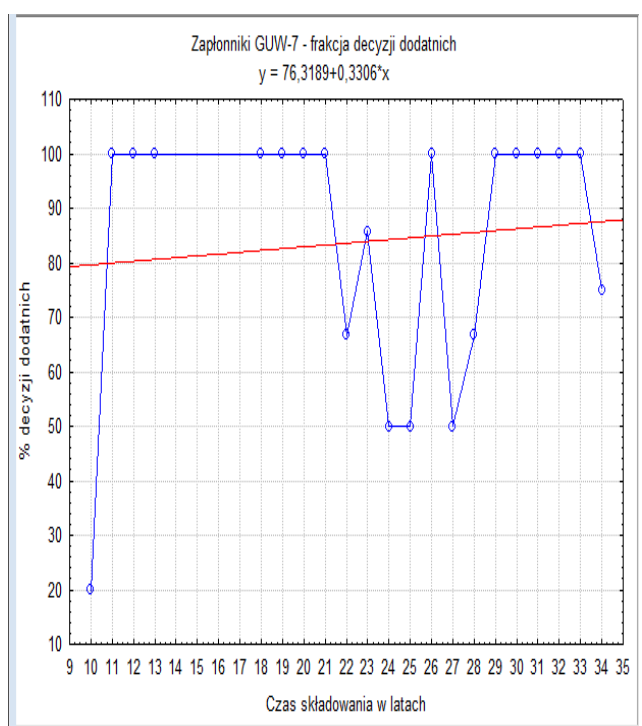

Rys.1 Wykres zależności między czasem sktadowania do chwili badania i frakcja decyzji dodatnich dla zapłonników GUW-7

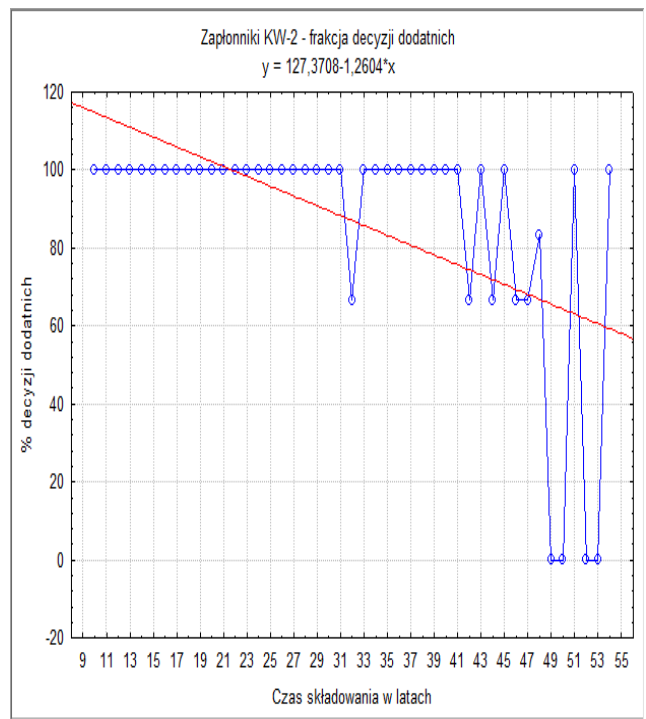

Rys.3. Wykres zależności między czasem sktadowania do chwili badania i frakcja decyzji dodatnich dla zapłonników $K W-2$

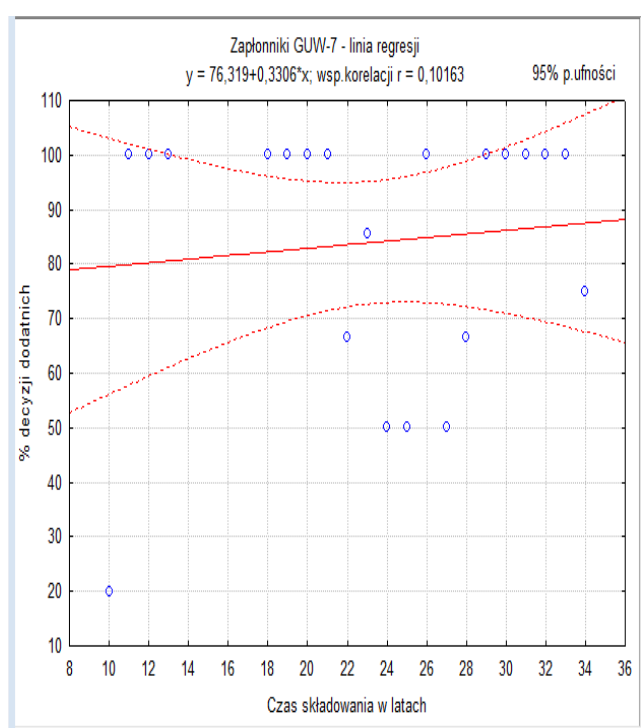

Rys. 2 Wykres rozrzutu danych oraz linia regresji opisujaca te dane łacznie z określonym przedziałem ufności dla zaptonników GUW-7

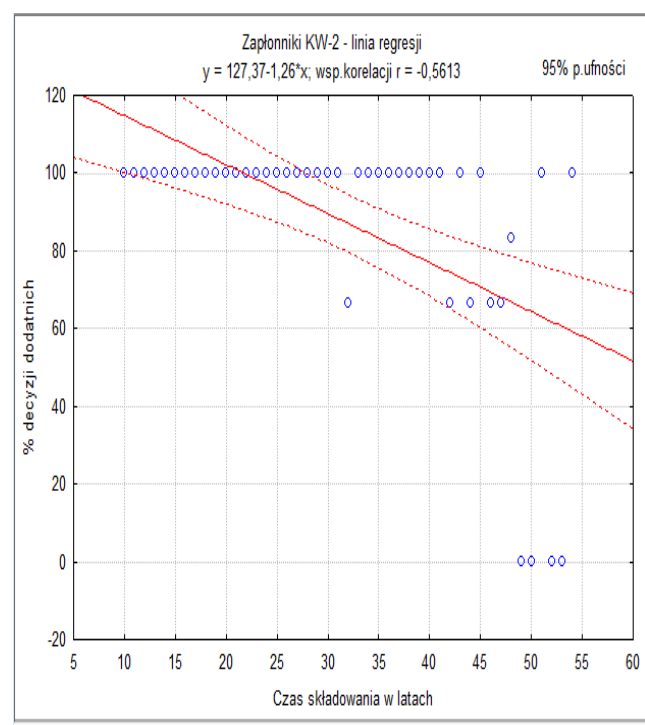

Rys.4. Wykres rozrzutu danych oraz linia regresji opisujaca te dane tacznie z określonym przedziałem ufności dla zapłonników $K W-2$ 
GUW-7 and $K W-2$ igniters types in the long-time storage process Zaptonniki typu GUW-7 i KW-2 w procesie dtugoletniego przechowywania

Ujemny współczynnik korelacji liniowej wynoszący $r=-0,5613$ informuje nas o dużym spadku tej frakcji w miarę wzrostu czasu składowania.

Przebiegi krzywych na rysunkach $1 \div 4$ wskazują na istnienie niedużej tendencji rosnącej dla zapłonników GUW-7 oraz o znacznej tendencji malejącej frakcji decyzji dodatnich dla zapłonników KW-2. Upływający czas, wpływa więc bardzo niekorzystnie na zapłonniki typu KW-2 gdyż pogarsza nam stan jakościowy tych zbiorów partii zapłonników długoletnio składowanych.

\section{Wpływ cyklu badania na decyzje}

Prowadzone badania diagnostyczne zbiorów partii zapłonników są czynnikiem mogącym mieć wpływ na jakość długotrwale składowanych zbiorów zapłonników. $\mathrm{W}$ wyniku tych systematycznych badań ze zbioru usuwane są partie niezgodne $\mathrm{z}$ wymaganiami. W konsekwencji w kolejnych cyklach badawczych jakość zbioru partii zapłonników powinna ulegać poprawie. W celu pełniejszego zbadania tego zjawiska przeprowadzono analizę zależności frakcji (procentu) decyzji dodatnich od czasu składowania w kolejnych cyklach badania. Jako zmienną niezależną przyjęto czas składowania, a jako zmienną zależną procent decyzji dodatnich. Na rysunkach $5 \div 11$ wykreślono otrzymane procenty decyzji dodatnich dla kolejnych cykli badania w zależności od czasu składowania odpowiednio dla zapłonników GUW-7 i KW-2 rozpatrywanych w tej analizie.

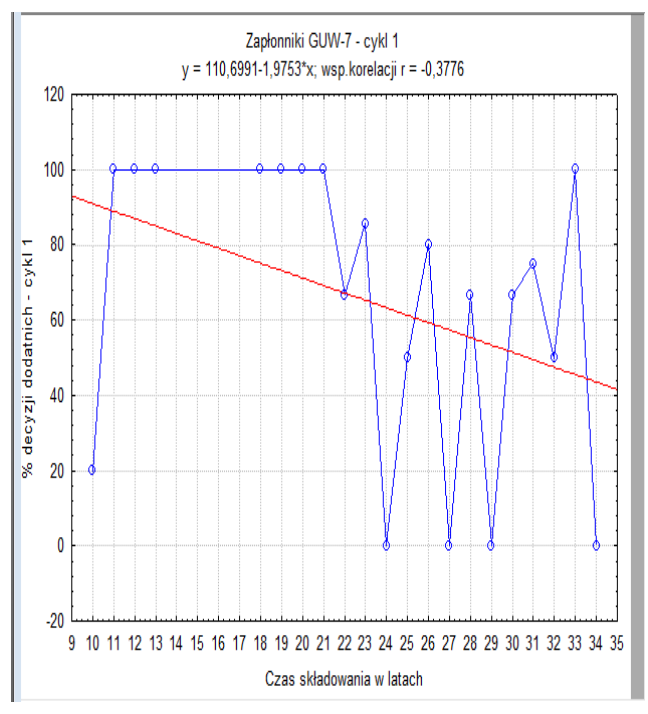

Rys.5 Frakcja decyzji dodatnich $w$ pierwszym cyklu badania $w$ zależności od czasu sktadowania dla zapłonników GUW-7

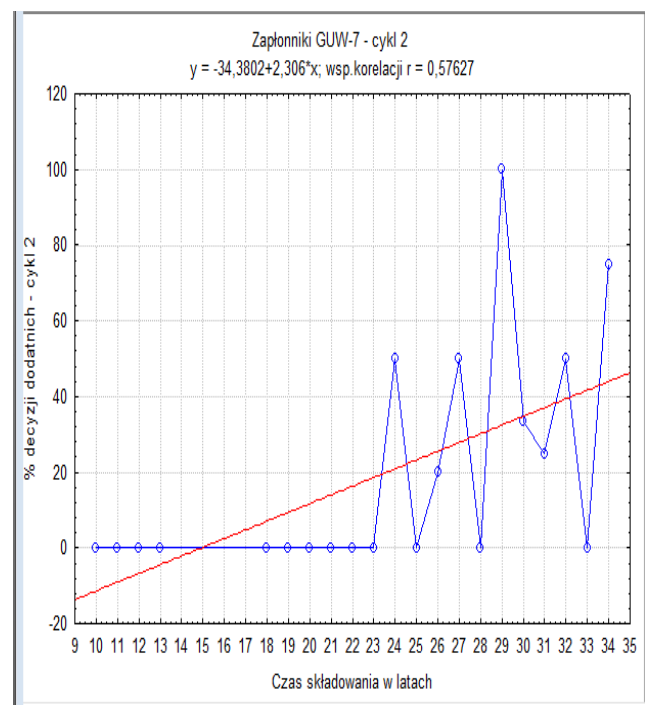

Rys.6 Frakcja decyzji dodatnich $w$ drugim cyklu badania $w$ zależności od czasu sktadowania dla zapłonników GUW-7 
Zapłonniki typu GUW-7 badane były tylko w dwóch cyklach badawczych, natomiast zapłonniki KW-2 aż w pięciu cyklach badawczych. Rysunek 5 pokazuje nam frakcję decyzji dodatnich podjętych w pierwszym cyklu badawczym w zależności od czasu składowania dla zapłonników GUW-7. Z wykresu tego wynika, że zależność ta ma tendencję spadkową o czym świadczy ujemny współczynnik korelacji $r=-0,3776$, czyli w miarę upływu czasu składowania następuje pogorszenie się poziomu jakości analizowanych zapłonników. Z rysunku 6, który pokazuje nam frakcję decyzji dodatnich podejmowanych w drugim cyklu badawczym widać, że frakcja ta ma charakter rosnący. Współczynnik korelacji liniowej wynosi $r=0,57627$, czyli następuje znaczna poprawa jakości zbioru składowanych partii zapłonników GUW-7 w tym cyklu badawczym.

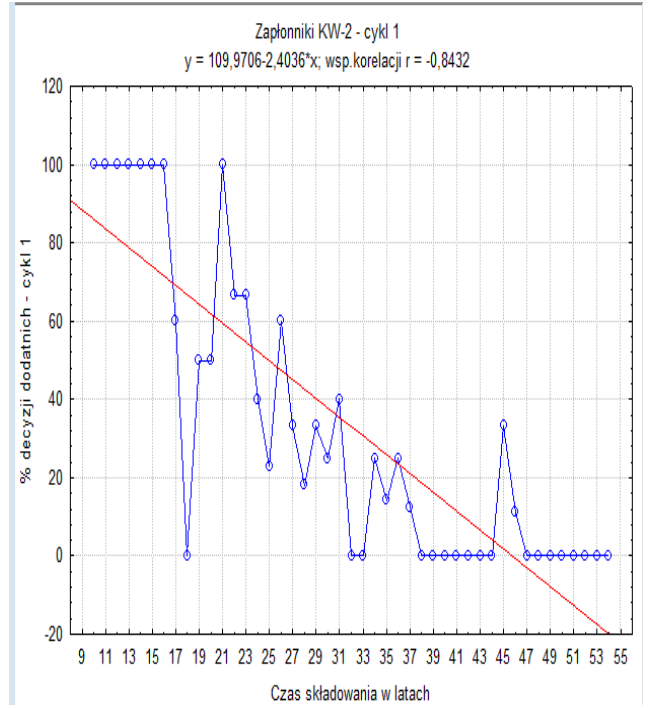

Rys.7. Frakcja decyzji dodatnich w pierwszym cyklu badania w zależności od czasu składowania dla zapłonników $K W-2$

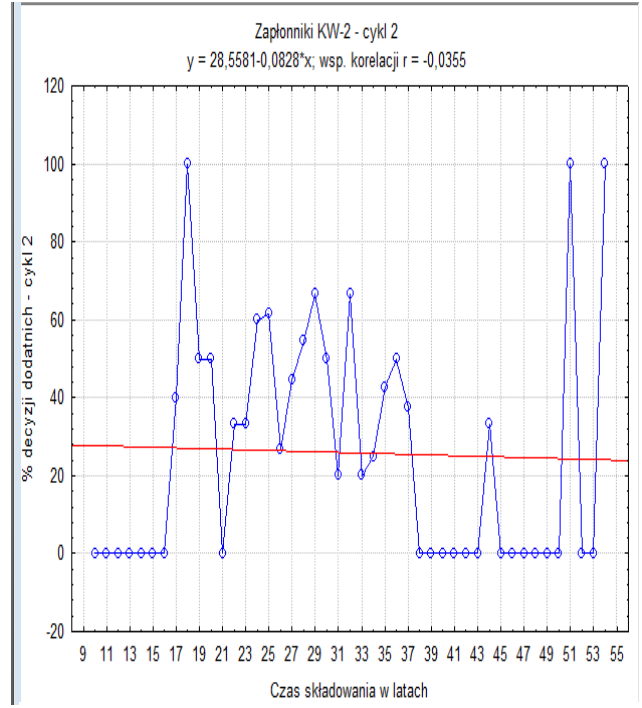

Rys.8. Frakcja decyzji dodatnich $w$ drugim cyklu badania $w$ zależności od czasu składowania dla zapłonników $K W-2$

Wykresy przedstawione na rysunkach $1 \div 11$ dotyczą zapłonników KW-2. Rysunek 7 pokazuje frakcję decyzji dodatnich podjętych w pierwszym cyklu badawczym w zależności od czasu składowania. Bardzo duża wartość współczynnika korelacji wynosząca $r=-0,8432$ mówi nam o gwałtownym spadku poziomu jakości zbiorów tych zapłonników. W drugim cyklu badawczym (rys. 8) widzimy praktycznie stały poziom jakości ponieważ krzywa regresji jest prawie pozioma $(r=-0,0355)$. Rysunki $9 \div 11$ pokazują frakcje decyzji dodatnich w kolejnych cyklach badawczych czyli od 3 do 5 .

We wszystkich tych cyklach widać, że krzywa regresji ma tendencję wzrastającą. Współczynniki korelacji liniowej wynoszą 0,23695 $\div 0,34449$. 
GUW-7 and $K W-2$ igniters types in the long-time storage process Zaptonniki typu GUW-7 i KW-2 w procesie dlugoletniego przechowywania

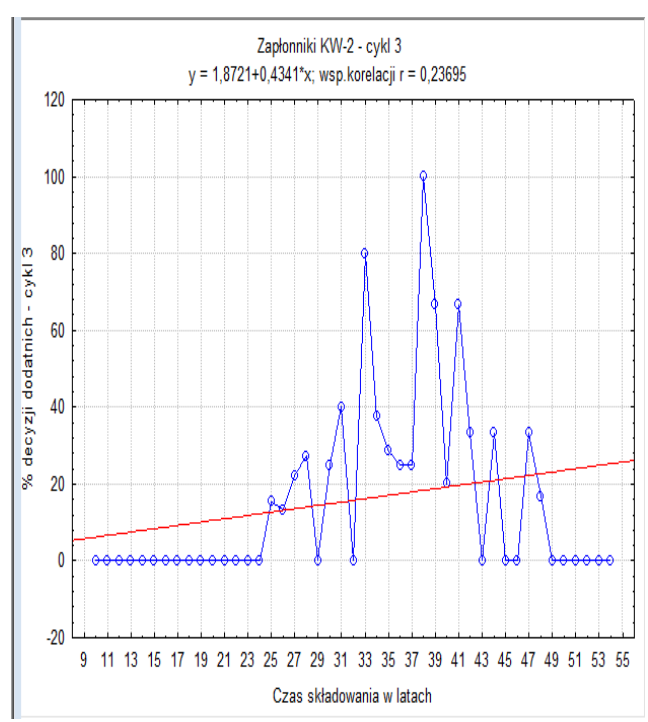

Rys.9. Frakcja decyzji dodatnich $w$ trzecim cyklu badania $w$ zależności od czasu składowania dla zapłonników $K W-2$

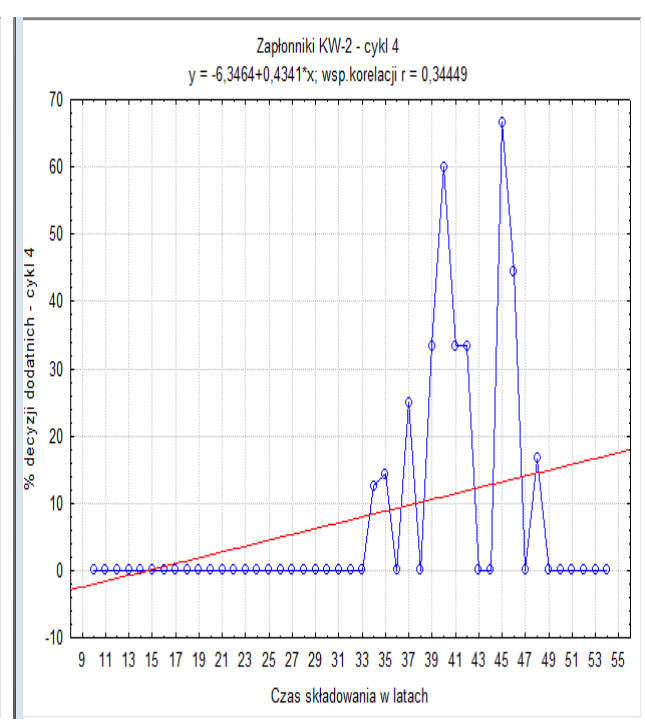

Rys.10. Frakcja decyzji dodatnich $w$ czwartym cyklu badania $w$ zależności od czasu sktadowania dla zapłonników $K W-2$

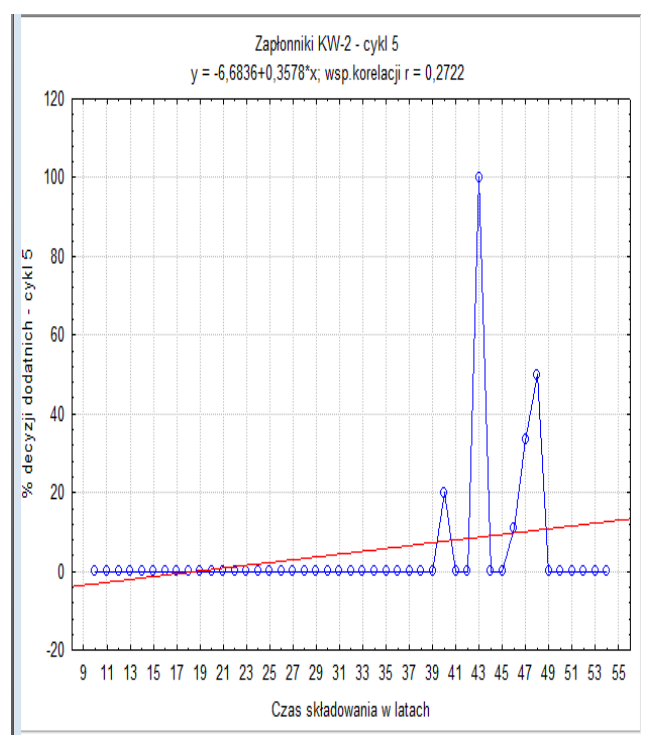

Rys.11 Frakcja decyzji dodatnich w piatym cyklu badania $w$ zależności od czasu składowania dla zaptonników KW-2. 


\section{Wpływ cyklu badania na występowanie niezgodności}

Podczas prowadzenia badań diagnostycznych, partia zapłonników zbadana w 1-wszym cyklu badawczym po 10 latach składowania, nie zawsze jest badana w 2-gim cyklu w 16-tym roku składowania. Także pierwszy cykl badania często jest rozpoczynany w różnych latach składowania. Głównie wiązało się to do tej pory $\mathrm{z}$ przydzielaniem corocznie coraz mniejszych środków finansowych na badania elementów amunicji. $\mathrm{W}$ analizie tej podjęto próbę określenia występowania niezgodności poszczególnych klas w zależności od kolejnego cyklu badania.

W przypadku zapłonników typu KW-2, wykreślenie takich krzywych było możliwe $\mathrm{z}$ uwagi na fakt, że zapłonniki te były badane w pięciu cyklach badawczych. Natomiast w przypadku zapłonników GUW-7, można wykreślić takie krzywe, jednakże będą to tylko linie proste o pewnym charakterze zmian z uwagi na fakt, że były one badane tylko w dwóch cyklach badawczych. Przy tak małej ilości danych (tylko dwa punkty) nie możliwe jest określenie na przykład współczynnika korelacji liniowej. Minimalna ilość obserwacji potrzebna do jego określenie to przynajmniej trzy punkty.

Z wyników danych opracowanych dla zapłonników typu GUW-7 wynika, że frakcja niezgodności danej klasy w zależności od cyklu badawczego jest albo rosnąca jak w przypadku niezgodności klasy A i C, albo jest ona malejąca jak w przypadku niezgodności klasy B i D. Jednakże przedstawianie tych danych w postaci wykresów, nie wnosi wiarygodnych informacji jakie powinno się wysnuć po wykreśleniu takich krzywych. Zbyt mała ilość cyklów badawczych w przypadku tego typu zapłonników spowodowana jest zbyt mała ilością przeprowadzonych badań.

W przypadku zapłonników KW-2, frakcje niezgodności określonych klas w zależności od cyklu badawczego przedstawiają rysunki $12 \div 15$.

W przypadku niezgodności klasy A i B mamy do czynienia z bardzo dużym spadkiem frakcji niezgodności tych klas. Współczynniki korelacji wynoszą dla niezgodności klasy A $r=-0,8908$ (rys. 12), a w przypadku niezgodności klasy B współczynnik ten wynosi $r=-0,929$ (rys. 13). Natomiast dla niezgodności klasy C i D mamy do czynienia ze wzrostem frakcji niezgodności tych klas. Współczynniki korelacji wynoszą dla niezgodności klasy $\mathrm{C} r=0,81193$ (rys. 14), a dla niezgodności klasy $\mathrm{D} r=0,70711$ (rys. 15).

Jak widać z przedstawionych wykresów, charakter zmian tych krzywych jest różny w zależności od rozpatrywanej klasy niezgodności. Określenie jednolitych wniosków dotyczących wpływu określonych klas niezgodności na poziom jakości rozpatrywanych zbiorów partii zapłonników typu KW-2 jest bardzo trudny.

$\mathrm{Na}$ rysunkach tych, w celu dokładniejszego zobrazowania charakteru zmian, wykreślono także linie regresji dla tych analizowanych zapłonników. 
GUW-7 and $K W-2$ igniters types in the long-time storage process Zaptonniki typu GUW-7 i KW-2 w procesie dlugoletniego przechowywania

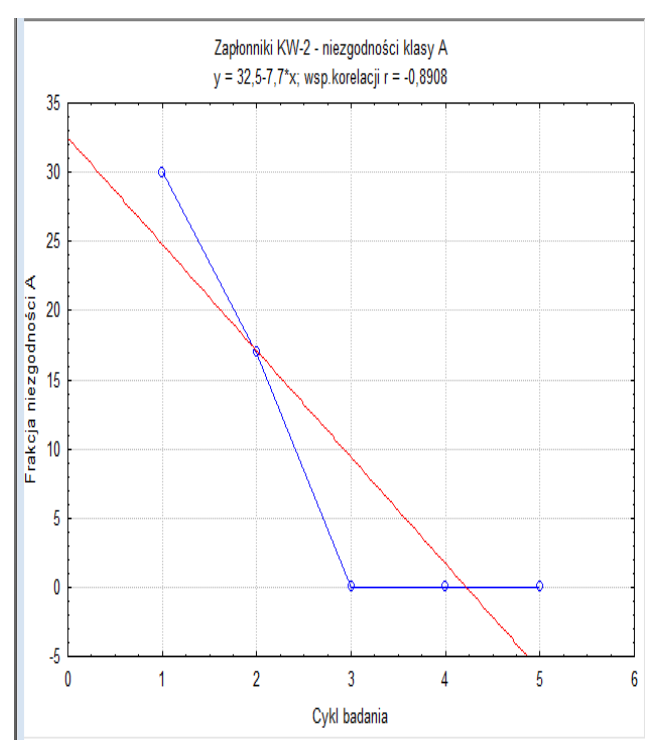

Rys.12. Frakcja niezgodności klasy A $w$ zależności od cyklu badania dla zapłonników $K W-2$

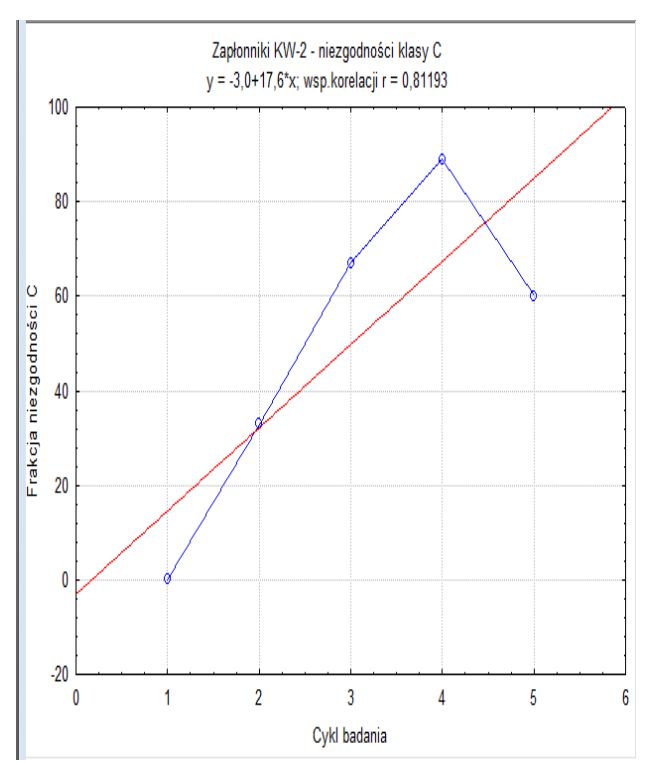

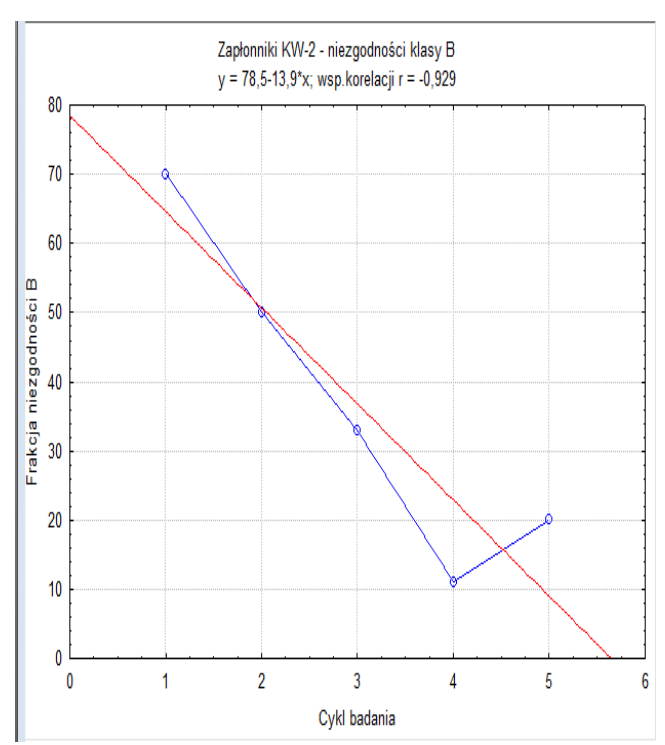

Rys.13. Frakcja niezgodności klasy B $w$ zależności od cyklu badania dla zapłonników $K W-2$

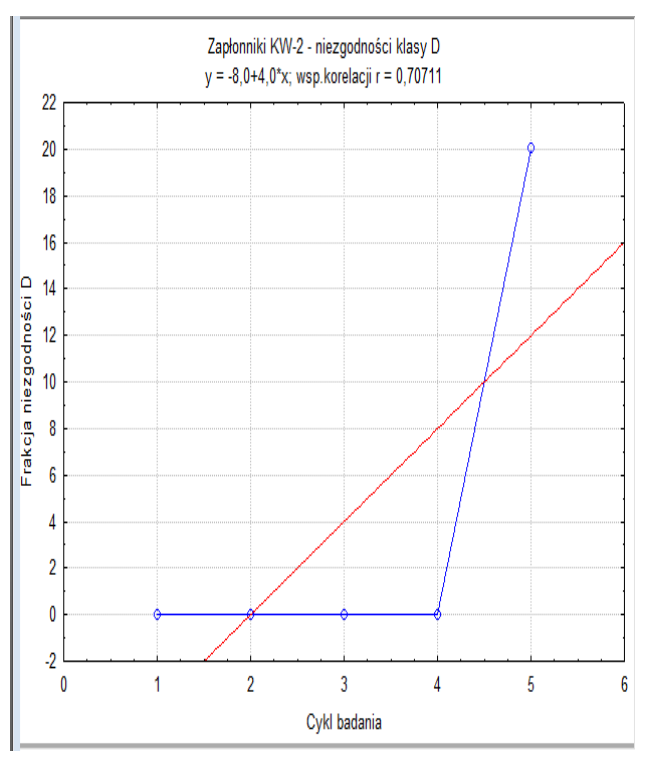

Rys.14. Frakcja niezgodności klasy $C w$ zależności od cyklu badania dla zapłonników $K W-2$
Rys.15. Frakcja niezgodności klasy D w zależności od cyklu badania dla zaptonników $K W-2$ 


\section{Wpływ czasu składowania na występowanie niezgodności}

Omawiana w punkcie 5 zależność występowania niezgodności określonej klasy od cyklu badania związana jest z czasem składowania. Kolejne cykle badania danej partii następują $\mathrm{w}$ późniejszych okresach składowania. Zależność ta nie jest funkcyjna, ponieważ rozpoczęcie pierwszego cyklu badania następuje w różnym czasie składowania partii, a ponadto czas upływający pomiędzy kolejnymi cyklami badania jest różny dla różnych partii składowanego zbioru. Kolejnym zatem przedmiotem analizy jest zależność frakcji próbek z niezgodnościami należącymi do poszczególnych klas niezgodności od czasu składowania partii zapłonników. Jako zmienną niezależną przyjęto więc czas składowania do chwili badania. Na rysunkach $16 \div 18$ przedstawiono frakcje próbek z niezgodnościami poszczególnych klas dla zapłonników analizowanych w tym artykule.

Na rysunku 16 przedstawiono wykresy zależności pomiędzy frakcją niezgodności klasy C w zależności od czasu składowania dla zapłonników typu GUW-7. W przypadku tej klasy niezgodności widzimy tendencję wzrostową co ewidentnie podkreśla fakt spadku jakości długoletnio składowanych zbiorów zapłonników tego typu. Współczynnik korelacji wynosi dla tej klasy niezgodności $r=0,23715$. Natomiast w przypadku niezgodności klasy A, B i D nie analizowano uzyskanych wyników ze względu na zbyt małą ilość otrzymanych niezgodności tych klas podczas przeprowadzonych badaniach.

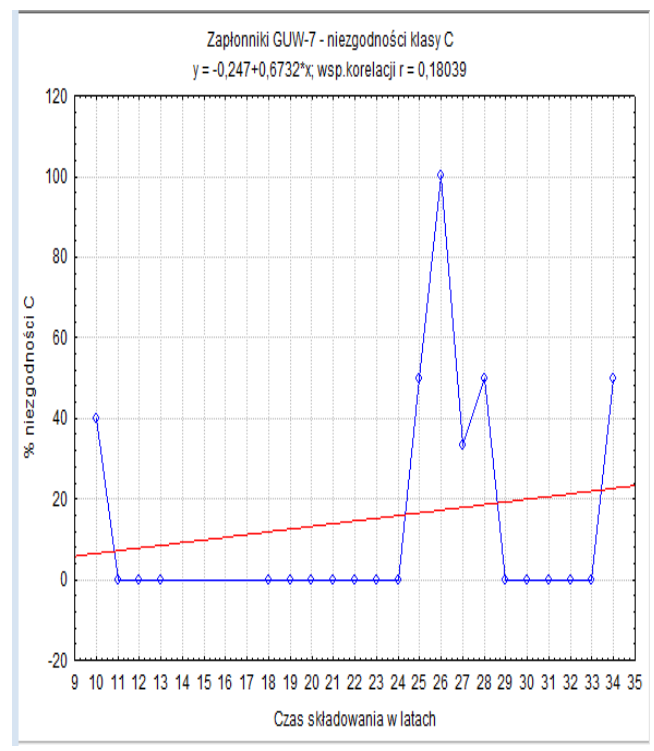

Rys.16. Frakcja niezgodności klasy C w zależności od czasu składowania dla zapłonników GUW-7 
GUW-7 and $K W-2$ igniters types in the long-time storage process

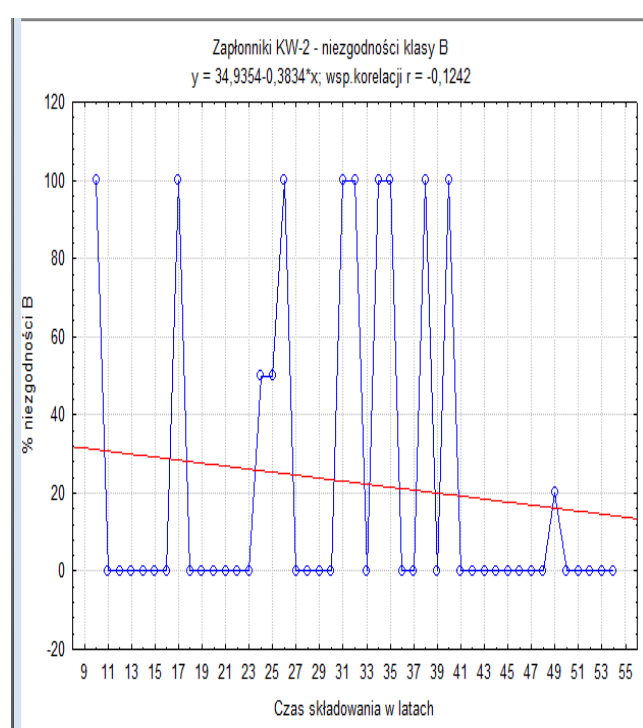

Rys.17. Frakcja niezgodności klasy B w zależności od czasu składowania dla zapłonników $K W-2$

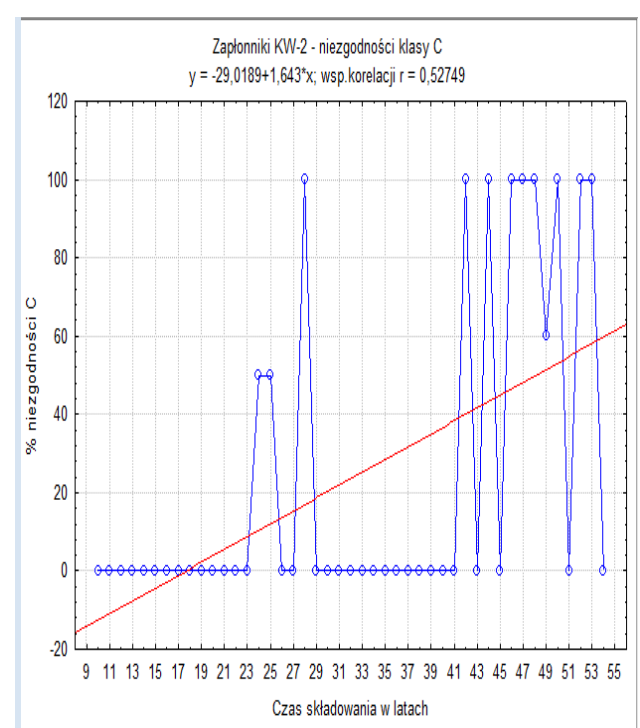

Rys.18. Frakcja niezgodności klasy C $w$ zależności od czasu sktadowania dla zaptonników $K W-2$

W przypadku zapłonników KW-2, frakcje niezgodności poszczególnych klas w zależności od czasu składowania zostały przedstawione na rysunkach 17 i 18 . W przypadku frakcji niezgodności klasy B (rys. 17) mamy do czynienia ze spadkiem frakcji niezgodności tej klasy. Współczynnik korelacji wynosi $r=-0,1242$. Natomiast dla frakcji niezgodności klasy $\mathrm{C}$ mamy do czynienia ze wzrostem frakcji niezgodności tej klasy. Współczynnik korelacji wynosi $r=0,52749$ (rys. 18). Frakcje niezgodności klasy A i D nie były rozpatrywane ze względu na zbyt małą ilość wyników badań niezgodności tych klas.

\section{Wnioski}

W przypadku analizowanych zapłonników zależność frakcji decyzji dodatnich od czasu składowania ma charakter nieznacznie rosnący i jest zależnością dodatnią dla zapłonników typu GUW-7, natomiast dla zapłonników typu KW-2 zależność ta ma charakter silnie malejący. Przebieg linii regresji wyraźnie wskazuje na fakt pogorszenia się stanu jakości zbiorów partii zapłonników tego typu w miarę upływu czasu składowania. 
Analiza zależności frakcji decyzji dodatnich w poszczególnych cyklach badawczych w zależności od czasu składowania wykazała, że frakcja ta ma różny charakter w zależności od rozpatrywanego cyklu badawczego.

Ma ona tendencję malejącą w przypadku cyklu pierwszego dla obu typów rozpatrywanych zapłonników oraz tendencję wzrastającą dla zapłonników KW-2 w cyklach badania od 3 do 5 i dla zapłonników GUW-7 w drugim cyklu badania.

W przypadku analizy zależności frakcji niezgodności poszczególnych klas w stosunku do cyklu badania widzimy, że frakcje te mają także różny charakter zmian w zależności od rozpatrywanego typu zapłonnika. Widać różne tendencje zmian niezgodności różnych klas dla analizowanych zapłonników. W przypadku zapłonników KW-2, niezgodności klasy A i B mają tendencję spadkową, czyli poprawia się poziom jakości tych zapłonników ze względu na te klasy niezgodności, natomiast niezgodności klasy C i D wykazują tendencję wzrostową, co może świadczyć o pogarszaniu się stanu jakościowego składowanych zapłonników ze względu na niezgodności tych klas. Zapłonniki typu GUW-7 wykazują także zmienną tendencję zmian w zależności od rodzaju niezgodności. Jednakże zbyt mała ilość cyklów badawczych dla tych zapłonników skutkuje brakiem możliwości opracowania wiarygodnych wykresów do przeprowadzanej analizy.

Analiza frakcji niezgodności poszczególnych klas w zależności od czasu składowania wykazała, że frakcja ta ma również różny charakter w zależności od rozpatrywanej klasy niezgodności i od typu zapłonnika. W przypadku zapłonników typu GUW-7, można było analizować tylko niezgodności klasy C, które mają tendencję wzrastającą w miarę upływu czasu składowania. Pozostałe niezgodności nie były analizowane $\mathrm{z}$ uwagi na zbyt mała ilość wyników badań w tych klasach niezgodności. W zapłonnikach KW-2 były analizowane niezgodności klas B i C. Niezgodności klasy B wykazały tendencję malejącą, natomiast niezgodności klasy $\mathrm{C}$ tendencję wrastającą.

W wyniku prowadzonych badań diagnostycznych usuwane są ze składowanego zbioru partie zapłonników niezgodne $\mathrm{z}$ wymaganiami, dzięki temu powinien poprawiać się poziom ich jakości lub utrzymywać na stałym dobrym poziomie jakościowym umożliwiającym normalną ich eksploatację. Niestety przeprowadzona analiza zapłonników typu GUW-7 i KW-2 nie potwierdza tego. Pomimo szerokiego zakresu tej analizy, uwzględniającego wiele możliwych rozpatrywanych wielkości, trudno jest wyciągnąć jednolite wnioski. W zależności od rodzaju analizowanych wielkości, tendencje zmian dla rozpatrywanych typów zapłonników są różne. 
GUW-7 and $K W-2$ igniters types in the long-time storage process Zaptonniki typu GUW-7 i KW-2 w procesie dlugoletniego przechowywania

\section{Literatura}

[1] Podręcznik - Amunicja wojsk lądowych - Ministerstwo Obrony Narodowej Szefostwo Służby Uzbrojenia i Elektroniki 1985 r.;

[2] Praca zbiorowa - Metodyka badań diagnostycznych amunicji - Indeks N5001b - 1985 r. Archiwum WITU;

[3] Statystyka 9 - Statsoft Polska 2009 r. - oprogramowanie komputerowe;

[4] M. Rabiej - Statystyka z programem Statistica - Wydawnictwo Helion, Gliwice 2012r.

[5] S. Kot, J. Jakubowski, A. Sokołowski - Statystyka - Wydawnictwo Difin, Warszawa $2011 \mathrm{r}$.

[6] Karty badań zapłonników - Archiwum WITU.

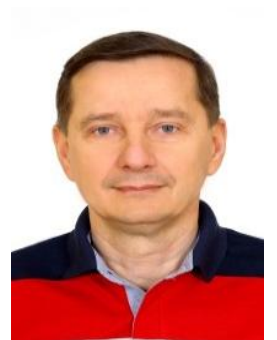

Dr inż. Dariusz Ampula, absolwent Wojskowej Akademii Technicznej w zakresie Systemów Uzbrojenia Naziemnego. Po odbyciu rocznej praktyki zawodowej zostat pracownikiem naukowo-badawczym $w$ Wojskowym Instytucie Technicznym Uzbrojenia w Zielonce. Stopień naukowy doktora uzyskat w 2006 roku $w$ Instytucie Technicznym Wojsk Lotniczych. Autor $i$ wspótautor prac z zakresu diagnostyki technicznej oraz niezawodności działania lądowych środków bojowych. $W$ swoich analizach badawczych skupia sie na problemach procesu predykcji badanych elementów amunicji ladowej. 